\section{BEYOND THE SOVIET THREAT}

\section{Rethinking American Security Policy in a New Era \\ William Zimmerman, Editor \\ The contributors explore the policy implications of the collapse of the Soviet Union, analyzing the dynamics of U.S.- Soviet interactions and the prospects for peace and security. \\ cloth $\$ 34.50$

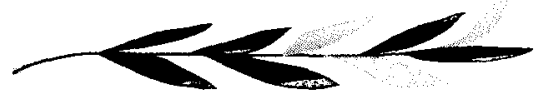 \\ PEACE}

An Idea Whose Time Has Come Anatol Rapoport

In this remarkable book, noted mathematician and peace researcher Anatol Rapoport charts the evolution of the idea of peace and explains why it is displacing war as a viable institution. cloth $\$ 29.95$

\section{UNCERTAIN}

\section{PERCEPTIONS}

\section{U.S. Cold War Crisis Decision Making \\ Robert B. McCalla}

McCalla examines the role played by misperception and rigidity of worldview in decisions made by U.S. officials during five Cold War crises.

cloth $\$ 34.50$

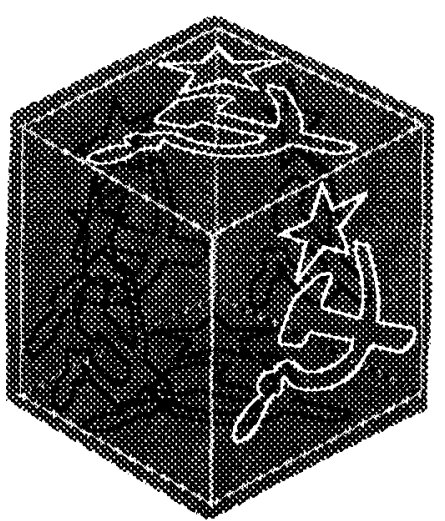

\section{IMAGES AND} ARMS CONTROL

Perceptions of the Soviet Union in the Reagan Administration

\section{Keith L. Shimko}

A study of foreign policy decision making as seen in the relationship between Reagan administration officials and their counterparts in the Soviet Union.

cloth $\$ 37.50$

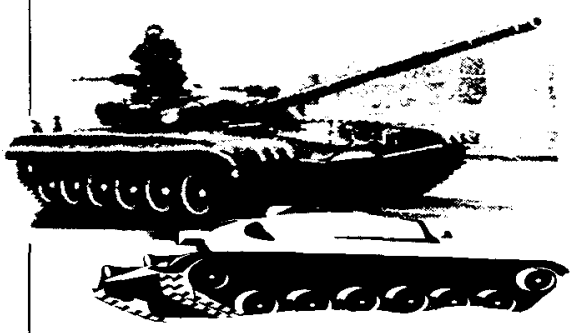

The University of Michigan Press Dept. AF

Ann Arbor, Michigan 48106-1104 


\section{Studies in Comparative International Development}

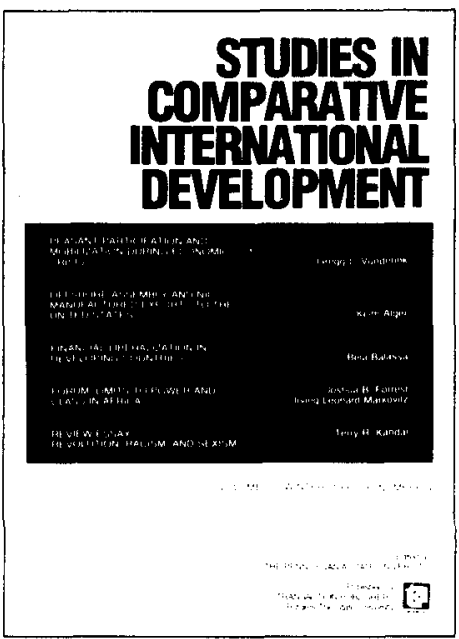

John D. Martz, Editor

The Pennsylvania State University

An interdisciplinary journal exploring current issues in development theory and practice. Open to all theoretical, methodological, and ideological approaches in examining the relationship between population, technology, and policy in a developmental context.

\section{Recent Articles:}

Rectification at Three: Impact on the Cuban Economy Jorge F. Pérez-López

The Politics of Adjustment in Kenya and Zimbabwe: The State as Intermediary

Howard P. Lehman

Peasant Participation and Mobilization During Economic Crisis: The Case of Costa Rica

Gregg L. Vunderink

Financial Liberalization in Developing Countries

Bela Balassa

Forum: The Conceptual Limits to Power and Class in Africa

Joshua B. Forrest, Irving Leonard Markovitz

Published Quarterly

Subscription rates:

Individuals: $\$ 36 / \mathrm{yr} ; \$ 72 / 2 y r s ; \$ 98 / 3 y r s$

Institutions: $\$ 76 / y r ; \$ 132 / 2 y r s ; \$ 174 / 3 y r s$

Domestic first-class mail add $\$ 20 / y r$

Foreign surface mail add $\$ 20 / y r$

Foreign airmail add $\$ 40 / y r$

Bound volumes available, please inquire. 


\section{COOPERATION AND CONFLICT}

\section{RECENT CONTENTS}

- Does Cooperation Inhibit War Kjell Goldman

- Problems of Enlargement: Political Integration

Thomas Pedersen

- Swans Scolding the Tiger? Scandinavian Foreign Policies towards Democratization in China, 1976-90

\section{Clemens Stubbe Østergaard}

- The Democratic Victory: What Will Happen to Foreign Policy? Hans Henrik Holm

- East-West Conflict and European Neutrality Bengt Sundelius

\section{Now published by Sage!}

Edited by Christian Thune Institute of Political Science, University of Copenhagen

This important journal reflects the vitality and diversity of contemporary Scandinavian international relations research and addresses vital issues in the scholarly search for a better grasp on the complexities of world affairs.

Published in February, May, August and November

Make sure you subscribe now!

\section{Use the order form below and save $20 \%$}

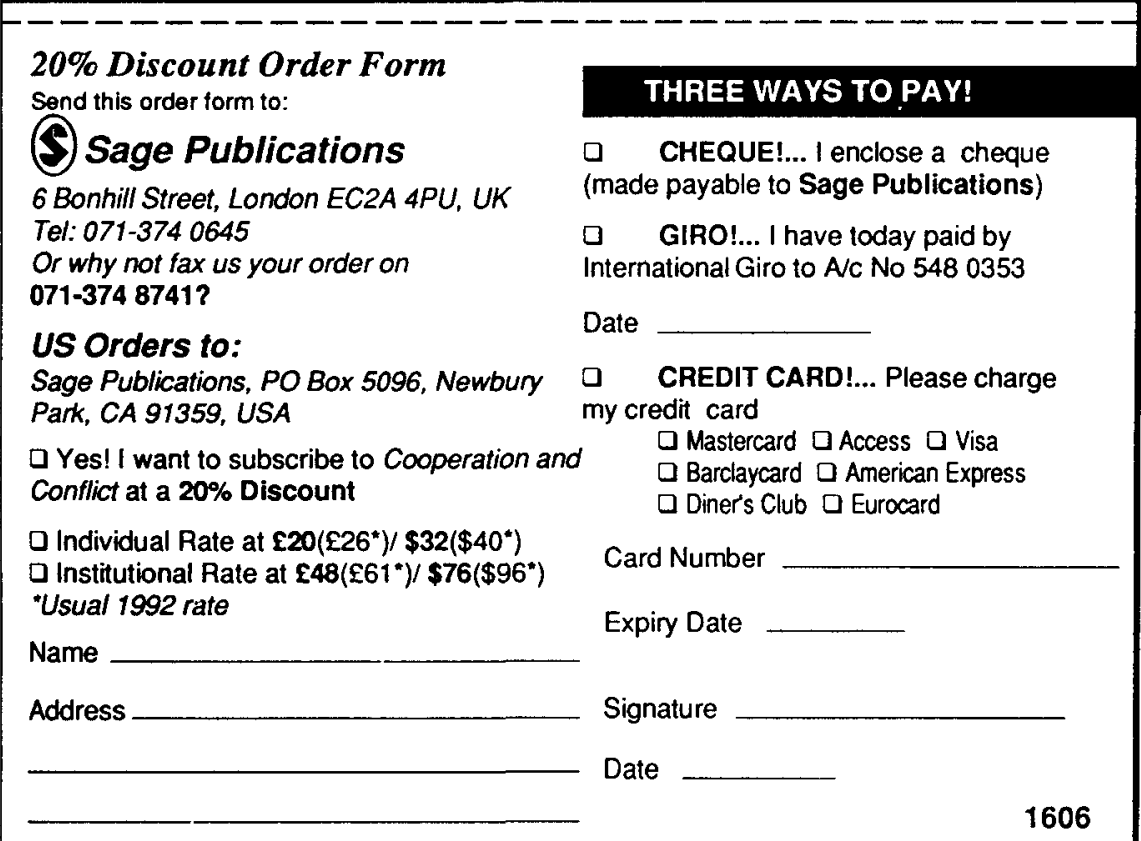




\section{Can you afford not to subscribe to The Australian Journal of Chinese Affairs}

Should be regularly consulted by everybody who wants to keep abreast of developments in the academic disciplines concerned with China.

Jurgen Domes, University of Saarlandes, Germany

The single best scholarly journal on contemporary China. If one has to limit oneself to one journal on China, it should be the $A / C A$.

Edward Friedman, University of Wisconsin

The $A J C A$ is the liveliest periodical in the field of contemporary Chinese studies. Feisty, enterprising, informed, and current.

Andrew J. Nathan, Columbia University

Up-to-date research, fresh ideas, and the thoughts of the leading specialists on all aspects of contemporary China. Lucian Pye, MIT

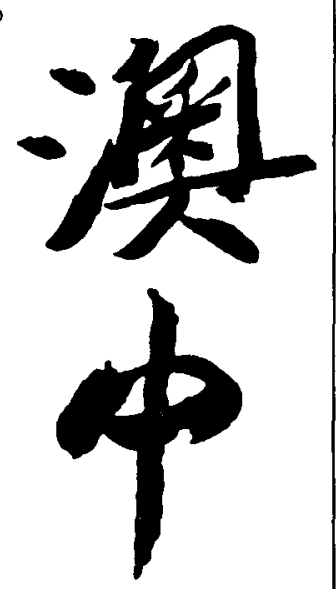

Now clearly the best journal in the field. Consistently insightful. It is a must for every China scholar's fingertips.

Frederick Teiwes, University of Sydney

Currently the most interesting journal in the field. Andrew Walder, Harvard University

The $A / C A$ is fast becoming the leading journal of contemporary Chinese studies. This is one of the few journals that I read cover to cover. James L. Watson, Harvard University

Has now become must reading for any serious student of contemporary China. Martin K. Whyte, University of Michigan

Subscription Rates ( 2 issues per annum, each issue 230 pages):

Within Australia: $\$ 25$ per year; students $\$ 20$; institutions $\$ 30$.

Outside Australia US\$25 per year; institutions US\$30; students US $\$ 20$. Or the equivalent in local currency.

New three-year subscriptions: $\$ 60 /$ US $\$ 60$ (institutions $\$ 75$ ) plus a complimentary copy of issue 28.

Back issues Nos $7,10,12$ to 22 , and 24 to 28 can be purchased at $\$ 15 /$ US $\$ 15$ each. Subscriptions should be sent to: Contemporary China Centre, RSPacS, ANU, GPO Box 4, Canberra, 2601. 


\section{INTERNATIONAL SOCIAL SCIENCE JOURNAL}

\section{Edited by Ali Kazancigil}

"Each issue of the International Social Science Journal takes up a theme of broad social significance and presents research findings and syntheses from all parts of the world. Anyone wishing to obtain an interdisciplinary and global perspective on current world problems, from the micro to the macro levels, ought surely to read the ISSJ".

Fred W Riggs, University of Hawaii
Recent articles include:

Geographical information systems and environmental problems David Rhind

Patterns of democracy in South Asia S. D. Muni

Identity crises as a paradigm of Middle Eastem conflictuality Yves Besson

ORDER FORM

INTERNATIONAL SOCIAL SCIENCE JOURNAL

Subscription Rates, Volume 44, 1992

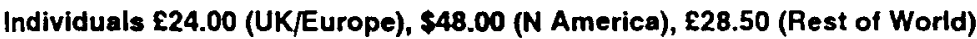

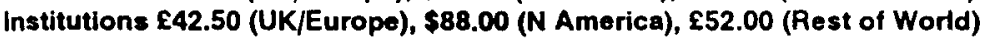

Published quarterly

Please enter my subscription/send me a sample copy

I enclose a cheque/money order payable to Basil Blackwell

Please charge my Access/American Express/Diners

Club/Mastercard/Visa account number

Expiry Date

For payments via the National Girobank, the Blackwell account number is 2366053

Name

Address

Postcode

Signature

Date

Payment must acoompany orders

Please return this form to: Journals Marketing Manager, Blackwell Publishers, 108 Cowley Road, Oxford, OX4 1JF. England. Registered No. 180277. Or to: Joumals Marketing, ISSJ, Blackwell Publishers, Three Cambridge Center, Cambridge, MA 02142. USA 


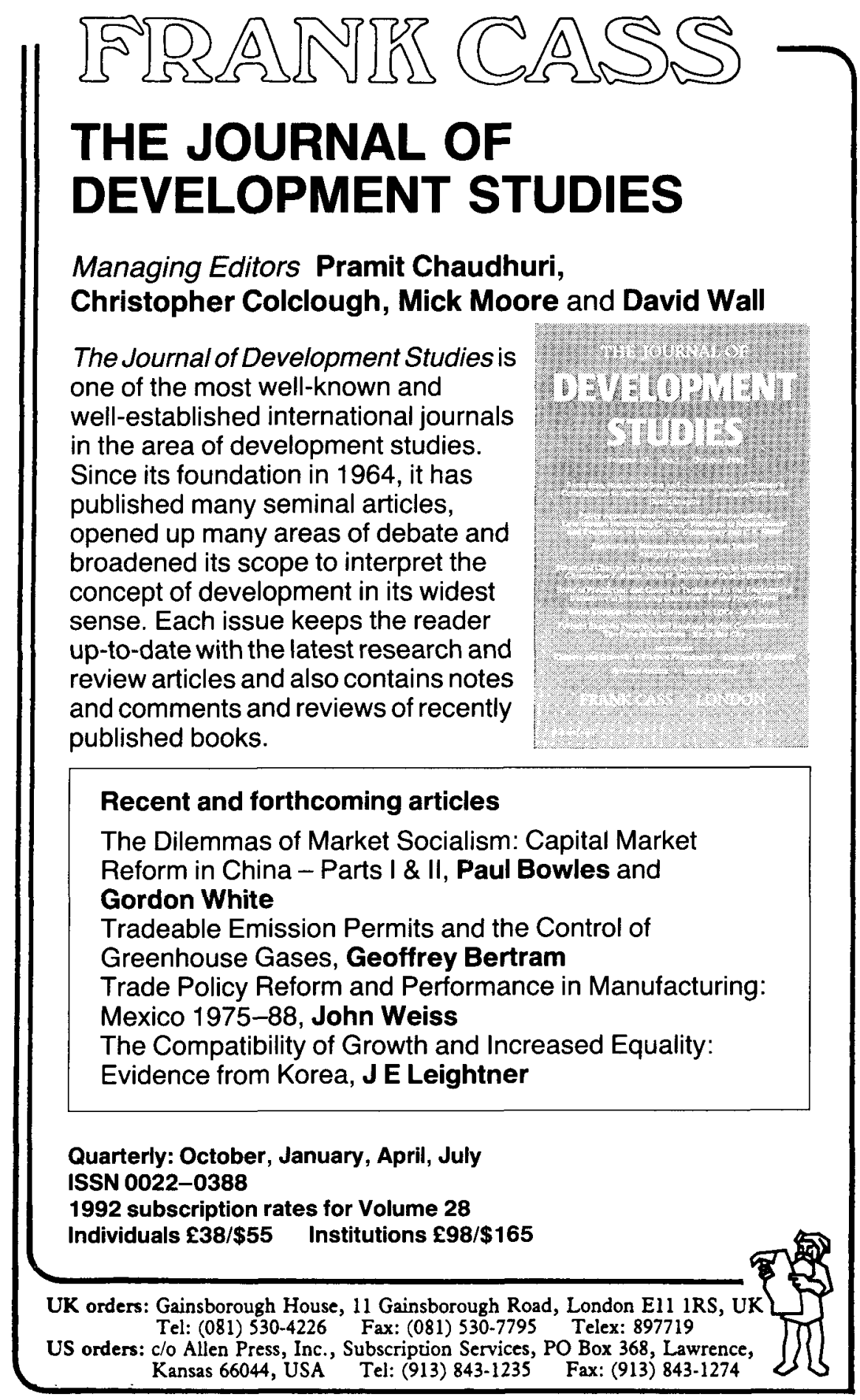




\section{SCANDINAVIAN JOURNAL OF DEVELOPMENT ALTERNATIVES Post Box 7444, 10391 Stockholm Sweden}

This is a journal with an interdisciplinary focus in the social sciences. It is both theoretical and practical nature, and seeks to confront and deal with every aspect of human development, covering all the socio-economic systems of the world. It has interest in such issues as basic social needs, fulfillment of human rights, avoidance of both class and other structural violence, the search for disarmament and peace, the maintenance of ecological balance, the removal of poverty and unemployment, improvement in North-South relations, and the finding of an international framework to deal equitably with trade, industrialization, migration, technology transfer, and general socio-economic disparities of a regional or a global kind.

Selected articles in recent issues

One Special Issue of Andre Gunder Frank (150 pages) entitled "The Underdevelopment of Development" which includes Frank's Bibliography of Publications 1955-1990, Chapters in Collections, Edited Books, Anthologies Latin American Development Theories Revisited, A Participant Review Essay. This issue includes the details of 110 books, 104 collections, and 600 periodical articles. This is useful to libraries and researchers.

Other articles include Forum on Aids Disease in Africa

Philippe Engelhard and Moussa Seck

Sexual Behavior and Cultural Context: With Special Reference to Senegal

Adebowale Akande

Understanding AIDS/HIV: Implications for Psychologists and Other Professionals in Africa

Sara Tallis and Scott Harris

Aids in East Africa: A Regional Assessment

A.I. Odebiyi, Sola Olowu and Franklin Vivekananda

Shame has Fallen on the Earth Now--Aids in Africa Psycho-Social and Economic Analysis

D.Okediji, E.O. Ojofeitimi, B.Feyisetan A.K. Ako-Nai and O. Taiwo

Knowledge Awareness and Attitudes of Acquired Immunodeficiency Syndrome (AIDS) of Health and Non-Health Professionals in University of Ife Community, Nigeria

Olatunde E. Okediji

Acquired Immune Deficiency Syndrome and African Population: an Update

A.I. Odebiyi

Socio-Cultural Factors and the Spread of AIDS: the Need for Health Education

A.I. Odebiyi and Franklin Vivekananda

Aids in Third World Countries: Africa-What Are the Alternatives

G. N. Vukor-Quarshie

Liability for AIDS: Infection Under the Criminal Law of Nigeria

Anselm Uba

AIDS in Africa: Some Alternative Solutions?

Amos K. Fabiyi

Health Education Holds the Key to Controlling the Spread of AIDS

Sobbie A.Z. Mulindi

Strategies for HIV Infection Prevention in a Developing Country: Case Study of Kenya.

Randolph Quaye

The Political Economy of Health and Medical Care: The Ghanaian Experience. 


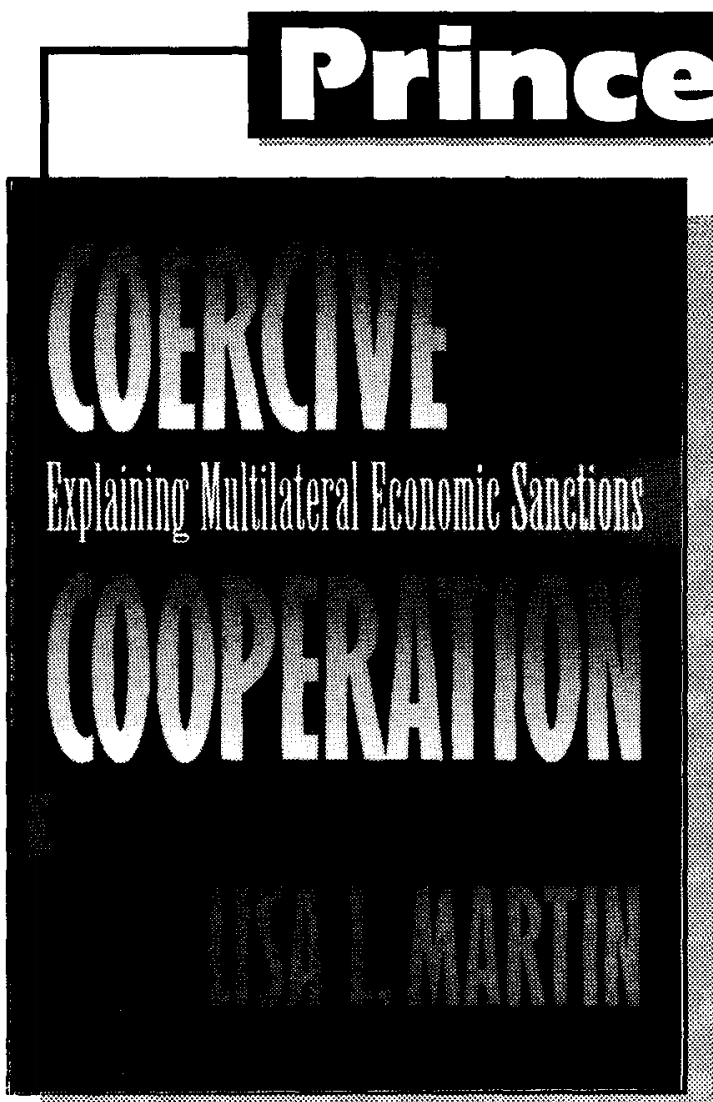

Coercive Cooperation Explaining Multilateral Economic Sanctions Lisa L. Martin

When Saddam Hussein's army invaded Kuwait, the United States took the lead in organizing stringent economic sanctions against Iraq. Since unilateral sanctions rarely succeed, "coercive cooperation" was a necessity. This innovative study shows that multilateral sanctions are coercive in their pressure on their target and in their origin: the sanctions themselves frequently result from coercive policies, with one state attempting to convince others through persuasion, threats, and promises. To analyze this process, Lisa Martin uses a novel methodology combining gametheoretic models, statistical analysis, and case studies. Cloth: $\$ 39.50$ ISBN 0-691-08624-9

\section{Cooperation and Governance in International Trade The Strategic Organizational Approach Beth V. Yarbrough and Robert M. Yarbrough}

International trade liberalization historically has taken many organizational formsunilateral, bilateral, minilateral, and multilateral. Given the proliferation of normative views about which of these should be pursued, economists and political scientists have devoted surprisingly little attention to the reasons for the observed variation in the chosen forms. This book is the first to develop a single theoretical framework to account for past liberalization practices and also to anticipate ongoing changes in the international organization of trade policy. Cloth: $\$ 35.00$ ISBN 0-691-04263-2

\section{Princeton University Press}

